\title{
SYNTHESIS OF NANOTUBES FROM MESOPOROUS NANOCRYSTALLINE TITANIUM DIOXIDE
}

\author{
N.I. ERMOKHINA, ${ }^{1}$ V.A. NEVINSKIY, ${ }^{1}$ P.A. MANORIK, ${ }^{1}$ V.G. ILYIN, ${ }^{1}$ \\ N.N. TSIBA, ${ }^{2}$ A.M. PUZIY, ${ }^{2}$ N.N. SHCHERBATYUK, ${ }^{3}$ D.O. KLYMCHYUK ${ }^{3}$ \\ ${ }^{1}$ L.V. Pysarzhevskyi Institute of Physical Chemistry, Nat. Acad. of Sci. of Ukraine \\ (31, Nauky Ave., Kyiv 03028, Ukraine; e-mail: v. a. nevinsky@gmail. com)
}

${ }^{2}$ Institute for Sorption and Problems of Endoecology, Nat. Acad. of Sci. of Ukraine (13, Gen. Naumov Str., Kyiv 03164, Ukraine)

PACS 81.07.De $\quad{ }^{3}$ M.G. Kholodnyi Institute of Botany, Nat. Acad. of Sci. of Ukraine

\begin{abstract}
Mesoporous nanocrystalline $\mathrm{TiO}_{2}$ (the anatase phase with spherical crystallites smaller than $10 \mathrm{~nm}$ and with the pore diameter larger than $17 \mathrm{~nm}$ ) is obtained by the sol-gel synthesis followed by a hydrothermal treatment. It is used for the fabrication of titanate nanotubes using the hydrothermal process in a concentrated aqueous $\mathrm{NaOH}$ solution at $130^{\circ} \mathrm{C}$. The SEM, TEM, XRD, and nitrogen adsorption-desorption methods were used to study the texture and morphology of new materials. Uniform nanotubular open-ended particles characterized by an average outer diameter of about $8 \mathrm{~nm}$ and a length larger than $1 \mu \mathrm{m}$ are observed. The particles are assembled into bundles about $64 \mathrm{~nm}$ in diameter, and the bundles were also aggregated. The calcination of titanate nanotubes in air at $300{ }^{\circ} \mathrm{C}$ gave rise to the formation of the anatase phase (the size of crystallite was $5.7 \mathrm{~nm}$ ), which was accompanied by a reduction of the specimen specific surface area from 255 to $190 \mathrm{~m}^{2} / \mathrm{g}$.
\end{abstract}

\section{Introduction}

Nanostructured $\mathrm{TiO}_{2}$-based materials-especially mesoporous ones, i.e. with the pore diameter ranging from 2 to $50 \mathrm{~nm}$-occupy one of the leading places among objects that are used in advanced nano-biotechnologies. Wide prospects of their application in various areas of medicine and biology are associated with a creation of novel biomaterials, such as biosensors, membrane reactors, containers for bioactive molecules (as new forms of pharmaceuticals), absorbers of microwave radiation, eco-photocatalysts, and others [1-6].

$\mathrm{TiO}_{2}$ crystallizes in the form of three basic polymorphs: anatase, rutile, and brookite. Anatase is believed to possess the highest bioactivity $[7,8]$. At the same time, there is a viewpoint [9] that rutile and anatase reveal the identical bioactivity, which is mainly governed by the size of their thin particles and the number of $\mathrm{OH}^{-}$groups. $\mathrm{TiO}_{2}$ films on the surface of biomet- als are referred to perfect biomaterials, because they are stable with respect to corrosion, chemically inert, and demonstrate a good compatibility with blood [5, 10-14]. Besides demonstrating the protective properties, $\mathrm{TiO}_{2}$ coatings also possess the ability to interact with the surface of bones in a specific manner $[15,16]$. Such a bioactivity is attributed to the formation of $\mathrm{OH}^{-}$groups on the $\mathrm{TiO}_{2}$ surface. Special advantages are connected by the researchers with coatings on the basis of titanic nanotubes characterized, along with a high specific surface, by a number of specific properties, for which the morphology of those materials is responsible $[6,17,18]$.

Earlier, we proposed an approach to the template solgel synthesis of mesoporous nanocrystalline $\mathrm{TiO}_{2}$ [19]. This method allowed us to obtain new $\mathrm{TiO}_{2}$-based materials, which are highly competitive with the known analogs by their textural characteristics and photocatalytic properties, being considerably better in some cases [20]. This work aimed at synthesizing the specimens of mesoporous nanocrystalline $\mathrm{TiO}_{2}$ (anatase) with various textural characteristics to be used as titanium sources in synthesizing the specimens of $\mathrm{TiO}_{2}$ nanotubes (TNT) and at studying the influence of the precursor nature on the nanotube structure and morphology.

\section{Experimental Part}

Specimens of mesoporous nano-sized $\mathrm{TiO}_{2}$ were synthesized using the sol-gel technique and subjected to a hydrothermal treatment following the routine proposed by us [19]. Titanium tetrabutoxide (TTBO, Aldrich) or titanium tetraisopropoxide (TTIP, Aldrich) served as titanium sources, whereas the crown ether dibenzo18-crown-6 (Fluka) in the form of its sodium complex $[\mathrm{Na}(\mathrm{DB} 16 \mathrm{C} 6)] \mathrm{Cl}$ as a template. The necessity of using the complex is associated with a very low solubility of 
$\mathrm{T}$ a b l e 1. Textural and structural characteristics of mesoporous nanocrystalline $\mathrm{TiO}_{2}($ anatase) specimens

\begin{tabular}{|c|c|c|c|c|c|c|c|}
\hline \multirow[t]{2}{*}{ No. } & \multirow{2}{*}{$\begin{array}{c}\mathrm{TiO}_{2} \\
\text { specimen }\end{array}$} & \multirow{2}{*}{$\begin{array}{l}\text { Titanium } \\
\text { alkoxide }\end{array}$} & \multirow{2}{*}{$\begin{array}{c}S_{\mathrm{sp}} \\
\mathrm{m}^{2} / \mathrm{g}\end{array}$} & \multirow{2}{*}{$\begin{array}{c}\text { Pore volume, } \\
\mathrm{cm}^{3} / \mathrm{g}\end{array}$} & \multirow{2}{*}{$\begin{array}{c}\text { Pore diameter, } \\
\mathrm{nm}\end{array}$} & \multicolumn{2}{|c|}{ Size of anatase crystallites, $\mathrm{nm}$} \\
\hline & & & & & & $\mathrm{XRD}$ & TEM \\
\hline 1 & $1 \mathrm{TiO}_{2}$ & TPOT & 110 & 0.66 & 23.0 & 8.4 & 8.8 \\
\hline 2 & $2 \mathrm{TiO}_{2}$ & TBOT & 78 & 0.41 & 21.0 & 7.3 & 8.0 \\
\hline 3 & $3 \mathrm{TiO}_{2}$ & TBOT & 117 & 0.69 & 23.5 & 8.1 & 8.3 \\
\hline 4 & $4 \mathrm{TiO}_{2}$ & TBOT & 100 & 0.51 & 20.4 & 7.0 & 7.7 \\
\hline 5 & $5 \mathrm{TiO}_{2}$ & TBOT & 86 & 0.69 & 17.3 & 9.0 & 9.0 \\
\hline
\end{tabular}

dibenzo-18-crown-6 in propanol and butanol, in which the synthesis was carried out. The hydrothermal treatment of specimens was carried out in a stainless steel autoclave at a temperature of $175^{\circ} \mathrm{C}$ for $24 \mathrm{~h}$. Calcination was carried out in air at a temperature of $500{ }^{\circ} \mathrm{C}$ for $4 \mathrm{~h}$.

$\mathrm{TiO}_{2}$ nanotubes were synthesized with the use of the alkaline hydrothermal process following a technique described in $[21,22]$. The specimens of synthesized mesoporous nanocrystalline $\mathrm{TiO}_{2}$ (anatase) were used as titanium sources. The hydrothermal treatment of specimens with a concentrated alkaline aqueous solution $(10 \mathrm{M}$ $\mathrm{NaOH})$ was carried out at a temperature of $130{ }^{\circ} \mathrm{C}$ for $24 \mathrm{~h}$. The specimens treated in such a way were separated by filtration and washed out: firstly in a considerable quantity of distilled water, then in a $0.1 \mathrm{M}$ solution of hydrochloric acid, and then again in distilled water until the $\mathrm{pH}$ of rinsing water became less than or equal to 7. The washed-out specimens of nanotubes were dried: firstly in air for $48 \mathrm{~h}$ and then at a temperature of $80^{\circ} \mathrm{C}$ for $7 \mathrm{~h}$. Calcination was carried out in air at a temperature of $300{ }^{\circ} \mathrm{C}$ for $4 \mathrm{~h}$.

A diffractometer Dron-3M $(\mathrm{CuK} \alpha)$ was used for the $\mathrm{X}$-ray phase analysis of the crystalline structure of the specimens obtained. The average size of $\mathrm{TiO}_{2}$ crystallites was calculated from the width of the anatase peak at $2 \Theta=25.4^{\circ}(101)$ in X-ray diffraction (XRD) patterns with the use of the well-known Scherrer equation.

The porous texture of $\mathrm{TiO}_{2}$ was described, by using the $\mathrm{N}_{2}$ adsorption-desorption isotherms at $77^{\circ} \mathrm{C}$ (system Autosorb-6, Quantachrome). Before the adsorption, the specimen was pumped out for $20 \mathrm{~h}$. The specific surface of specimens was determined following the BrunauerEmmett-Teller (BET) method. The distribution of pores over their dimensions was determined from the desorption branch of isotherm with the use of the NonLocalized Density Functional Theory (NLDFT) method. The total amount of $\mathrm{N}_{2}$ adsorbed at $p / p_{0}=0.997$ was used to determine the total volume of pores.

The morphology and the composition of specimens were studied using transmission electron microscopy (TEM, a microscope JEM-1230) and scanning electron microscopy (SEM, a microscope JEOL JSM-6060LA). A small amount of a powder was preliminary immersed into ethanol and stirred (or it was dispersed for $5 \mathrm{~min}$, by using ultrasound). For TEM researches, a solution droplet was placed onto a carbon film covering a copper grid. SEM micrographs were obtained after the covering of the tested specimens with a thin layer of gold.

\section{Results and Their Discussion}

In Table 1, the textural and structural characteristics of mesoporous $\mathrm{TiO}_{2}$ (anatase) synthesized using the solgel method and following our technique [19] are listed. One can see that $\mathrm{TiO}_{2}$ has well-developed surface in all specimens (the specific surface $S_{\mathrm{sp}}=78 \div 117 \mathrm{~m}^{2} / \mathrm{g}$ ), a considerable pore volume (from 0.41 to $0.69 \mathrm{~cm}^{3} / \mathrm{g}$ ), and large mesopores (more than $17 \mathrm{~nm}$ ).

In all specimens, $\mathrm{TiO}_{2}$ is in the pure anatase phase without rutile and brookite admixtures. The dimensions of spherical anatase crystallites (primary particles) do not exceed $9 \mathrm{~nm}$ according to the Scherrer equation. These primary spherical particles form agglomerates (secondary particles), which are nanospheres 35$40 \mathrm{~nm}$ in diameter. The secondary particles, in their turn, form larger mesopores. Hence, the mesopores compose a porous space within ensembles formed by secondary particles.

In Table 2, the textural characteristics of $\mathrm{TiO}_{2}$ nanotubes (marked as 1TNT to 5TNT) fabricated from the corresponding specimens of mesoporous $\mathrm{TiO}_{2}$ (marked as $1 \mathrm{TiO}_{2}$ to $5 \mathrm{TiO}_{2}$ ) using the alkaline hydrothermal method $[21,22]$ are presented. The crystalline structure and the morphology of nanotubes are known to depend on the synthesis conditions and the choice of the initial titanium source. All $\mathrm{TiO}_{2}$ polymorphs (anatase, rutile, and brookite) transform into nanotubular products at a hydrothermal synthesis temperature of $100-160{ }^{\circ} \mathrm{C}$, whereas the amorphous $\mathrm{TiO}_{2}$ forms produce nanofibrous $\mathrm{TiO}_{2}$ materials.

From the data exhibited in Tables 1 and 2, it follows that nanotubes, as well as initial $\mathrm{TiO}_{2}$ specimens, have different textural characteristics. The alkaline treatment 
results in the almost triple increase of the specific surface $S_{\mathrm{sp}}$ and a drastic reduction of the pore diameter in the specimens. Specimens 1TNT to 3TNT simultaneously demonstrate a very considerable reduction in the pore volume, whereas specimens $4 \mathrm{TNT}$ and $5 \mathrm{TNT}$, on the contrary, an increase of this parameter.

Figure 1 exhibits the diffraction patterns obtained for the specimen of initial titanium oxide $\left(5 \mathrm{TiO}_{2}\right)$ and the corresponding nanotube specimen (5TNT). Initial specimen $5 \mathrm{TiO}_{2}$ (Fig. 1,a) is anatase, because all the peaks are identified as reflexes (101), (004), (200), (105), and (211) of the anatase crystalline phase, whereas any attributes of reflexes typical of brookite and rutile are totally absent. The size of anatase crystallites is $9.0 \mathrm{~nm}$ according to the Scherrer equation. As one can see, the structure of nanotubes 5TNT (Fig. 1,b) differs radically from that of their precursor, specimen $5 \mathrm{TiO}_{2}$; namely, the anatase reflexes completely disappeared. The profile observed in the diffraction pattern for specimen 5TNT is similar to those presented in the works of other authors [4, 6, 23-25, 27-34].

Chen et al. $[25,27,29]$ considered that the observed diffraction peaks are much wider than the peaks typical of ordinary crystals, so that this profile, in view of the available literature data, cannot be related to any of the known $\mathrm{TiO}_{2}$ crystalline structures. On the other hand [25], all observed XRD peaks can be related to the $\mathrm{H}_{2} \mathrm{Ti}_{3} \mathrm{O}_{7}$ structure, which reveals the properties of weak Brønsted acid and can exist in alkaline solutions. With regard for the fact that the selected technique of washing out the fabricated nanotubes in an $\mathrm{HCl}$ solution results in that some number of $\mathrm{Na}^{+}$ions remain in them [24, 33, 34], we should adopt that the obtained titanate nanotubes are described by the formula $\mathrm{Na}_{x} \mathrm{H}_{2-x} \mathrm{Ti}_{3} \mathrm{O}_{7} \cdot n \mathrm{H}_{2} \mathrm{O}$. The peaks at about 10 and $28^{\circ}$ are typical of the Na-TNT form, and the H-TNT form is responsible for a wide peak between $2 \Theta=23^{\circ}$ and $25^{\circ}[24,33]$. The authors of work [24] revealed a consid-

$\mathrm{T}$ a b l e 2. Textural characteristics of $\mathrm{TiO}_{2}$ nanotube specimens fabricated from the corresponding specimens of mesoporous $\mathrm{TiO}_{2}$ (Table 1)

\begin{tabular}{c|c|c|c|c}
\hline No. & $\begin{array}{c}\text { Nanotube } \\
\text { specimen }\end{array}$ & $\begin{array}{c}S_{\mathrm{sp}}, \\
\mathrm{m}^{2} / \mathrm{g}\end{array}$ & $\begin{array}{c}\text { Pore volume, } \\
\mathrm{cm}^{3} / \mathrm{g}\end{array}$ & $\begin{array}{c}\text { Pore diameter, } \\
\mathrm{nm}\end{array}$ \\
\hline 1 & $1 \mathrm{TNT}$ & 269 & 0.25 & 3.7 \\
2 & $2 \mathrm{TNT}$ & 204 & 0.20 & 3.9 \\
3 & $3 \mathrm{TNT}$ & 191 & 0.17 & 3.6 \\
4 & $4 \mathrm{TNT}$ & 290 & 1.24 & 3.3 \\
5 & $5 \mathrm{TNT}$ & 254 & 0.73 & 9.4 \\
$6 *$ & $5 \mathrm{TNT}-300$ & 190 & 0.60 & 9.4 \\
\hline
\end{tabular}

*5TNT specimen after calcination at $300{ }^{\circ} \mathrm{C}$.

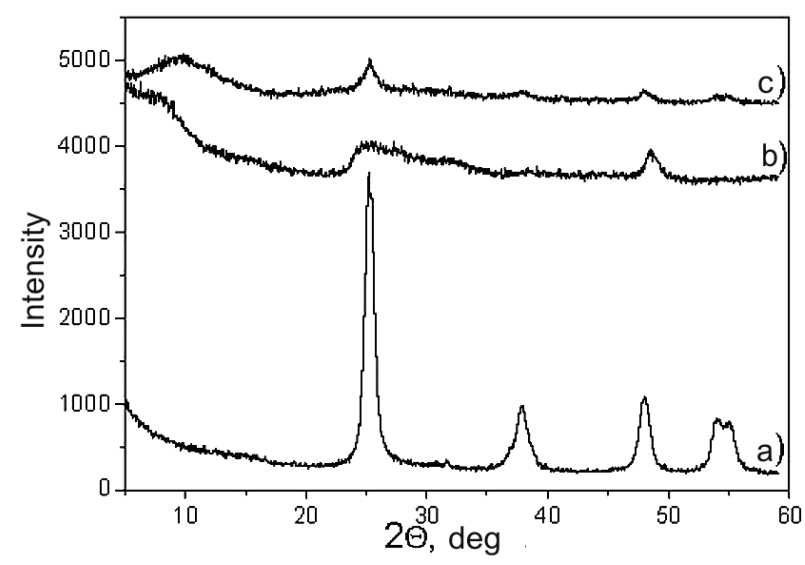

Fig. 1. Diffraction patterns for various specimens: $5 \mathrm{TiO}_{2}(a)$, 5TNT $(b)$, and 5TNT-300 (c)

erable amount of water in nanotubes and came to the conclusion that $\mathrm{Na}^{+}$ions are not only in the physically adsorbed state but also partially enter into the crystal lattice.

The results of TEM and SEM studies of $5 \mathrm{TiO}_{2}$ and 5TNT specimens are shown in Figs. 2 and 3 . From Figs. 2, $a$ and $b$, one can see that initial titanium dioxide is uniform and is characterized by the spherical shape of primary particles (the size of anatase crystallites of $9.0 \mathrm{~nm}$ coincides with that calculated from the Scherrer formula). The corresponding electron diffraction pattern is depicted in Fig. 2,a. Primary particles form spherical agglomerates about $40 \mathrm{~nm}$ in diameter (secondary particles). The latter, in turn, are assembled into micrometersized spheroidal particles (Fig. 3,a) and form mesopores in them.

As follows from the TEM data (Figs. 2,c and $d$ ), the fabricated titanate nanotubes (specimen $5 \mathrm{TNT}$ ) are pure (without an admixture of $5 \mathrm{TiO}_{2}$ precursor particles) homogeneous nanotubular particles with a smooth surface, which are open at both ends and have a diameter of about $8 \mathrm{~nm}$. The results of SEM analysis (Figs. 3,b and $c$ ) demonstrate that the nanotubes are assembled into uniform bundles about $64 \mathrm{~nm}$ in diameter and more than $1 \mu \mathrm{m}$ in length. The bundles form ensembles 2.7 to $3.2 \mu \mathrm{m}$ in size (Fig. 3,b), which resemble a colony of sea corals.

It was found that, when the nanotubes are heated up in air, anatase in their walls crystallizes, which is testified by the appearance of characteristic reflexes in the diffraction pattern of 5TNT-300 specimen (Fig. 1,c). Nanotube calcination at $300{ }^{\circ} \mathrm{C}$ for $4 \mathrm{~h}$ gives rise to the formation of the crystalline anatase phase with crystallites $5.7 \mathrm{~nm}$ in size. As is seen from the TEM (Figs. 2,c-f) 

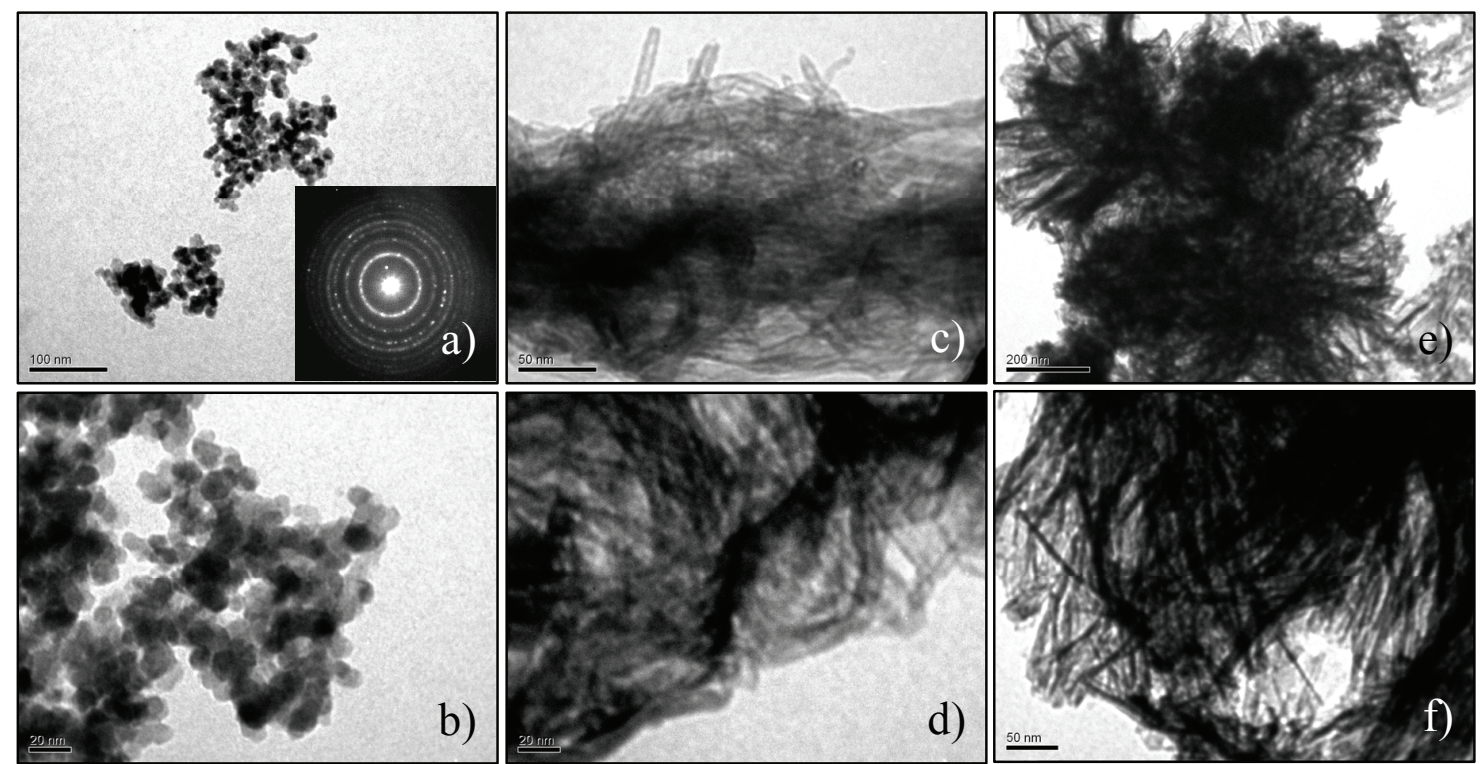

Fig. 2. TEM images for various specimens at various zooms: UV-treated $5 \mathrm{TiO}_{2}$ ( $a$ (with the electron diffraction pattern) and $b$ ), $5 \mathrm{TNT}$ $(c$ and $d)$, and 5TNT-300 $(e$ and $f)$

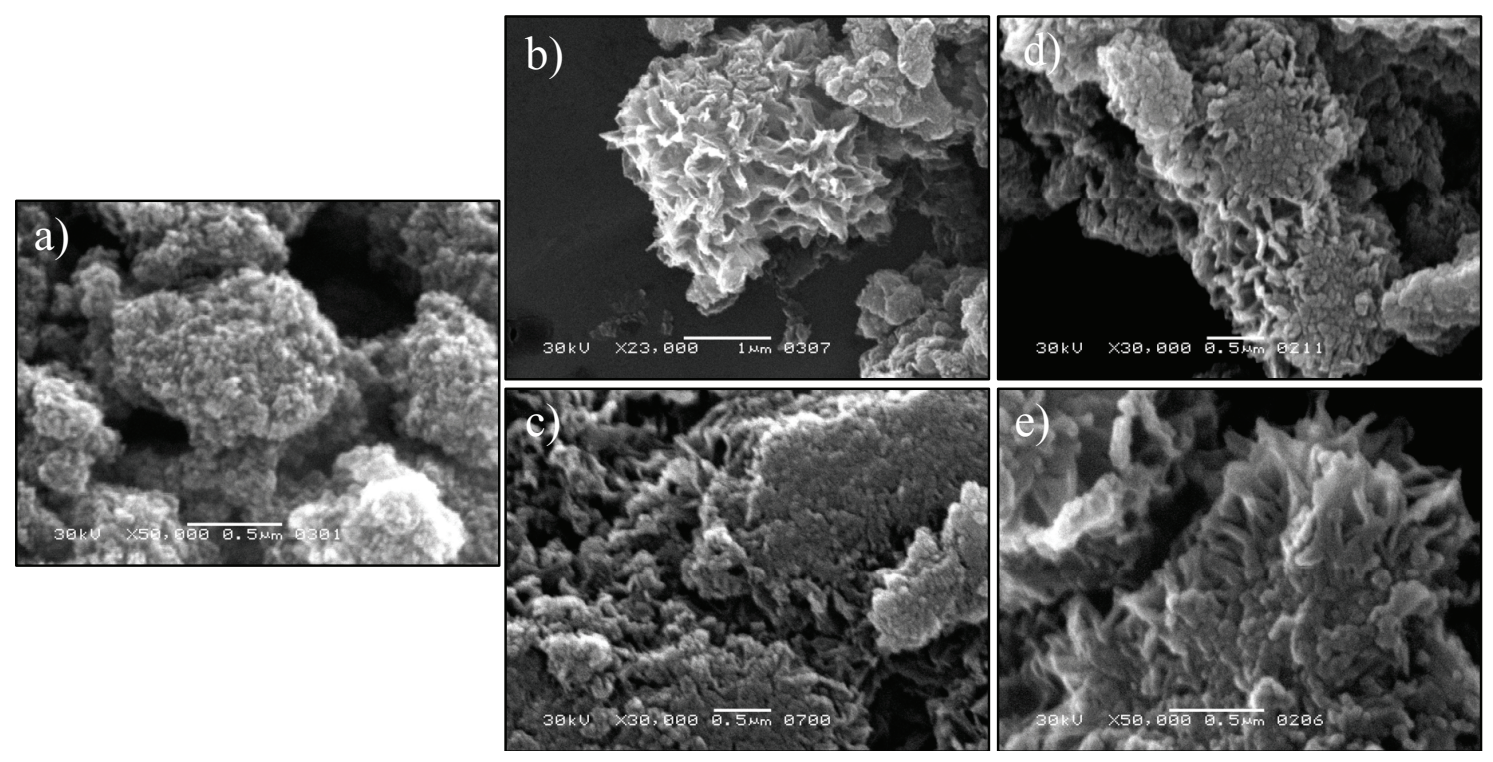

Fig. 3. SEM images for various specimens at various zooms: $5 \mathrm{TiO}_{2}(a), 5 \mathrm{TNT}(b)$, UV-treated 5TNT $(c), 5 \mathrm{TNT}-300(d)$, and UV-treated 5TNT-300 (e)

and SEM (Figs. 3,b-e) data, the morphology of 5TNT300 specimen does not differ substantially from that of 5TNT specimen. However, it should be noted that, after calcination, the average diameter of nanotube bundles decreased from 64 to $53 \mathrm{~nm}$ (Figs. 3,b-e).

In Fig. 4, the $\mathrm{N}_{2}$ adsorption-desorption isotherms for the initial $5 \mathrm{TiO}_{2}$ specimen and titanate nanotubes be- fore calcination and the corresponding curves for the size distributions of pores are depicted. All the specimens demonstrate the isotherms of type IV, which evidences the presence of uniform mesopores $(2-50 \mathrm{~nm})$ in those materials [35].

The specific surface in initial $5 \mathrm{TiO}_{2}$ specimen equals $86 \mathrm{~m}^{2} / \mathrm{g}$. In the corresponding nanotube specimen 

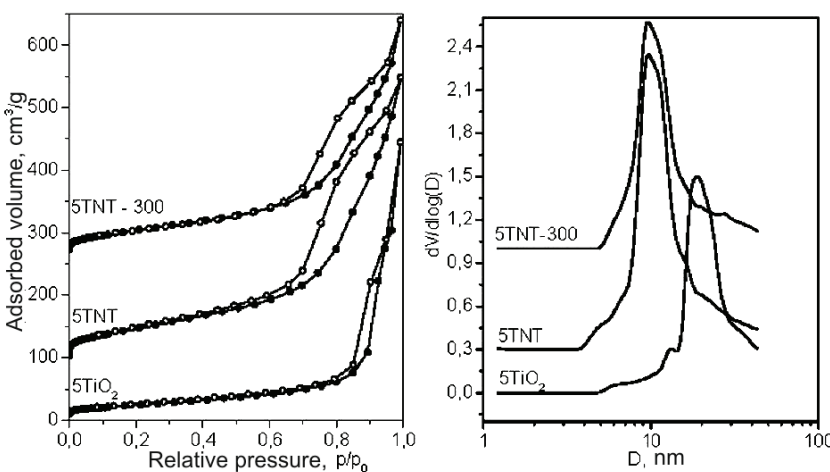

Fig. 4. $\mathrm{N}_{2}$ adsorption-desorption isotherms for $5 \mathrm{TiO}_{2}, 5 \mathrm{TNT}$, and 5TNT-300 specimens and the corresponding NLDFT distributions of pores over their dimensions

5TNT, this parameter is very high and equals $254 \mathrm{~m}^{2} / \mathrm{g}$. In the course of nanotube heating, the specific surface diminishes and reaches the value of $190 \mathrm{~m}^{2} / \mathrm{g}$ for specimen 5TNT-300. The pore diameter of $9.4 \mathrm{~nm}$ in specimen 5TNT obtained by this technique differs from the average value determined from the TEM data (the internal diameter of nanotubes is about $4 \mathrm{~nm}$ ), because not only the intra- but also the intertube pore space is taken into account [4].

\section{Conclusions}

In the majority of procedures, which are aimed at fabricating the titanate nanotubes and described in the literature, it is supposed that nonporous trademarked $\mathrm{TiO}_{2}$ substances are used as precursors. By applying the technique proposed by us earlier, we synthesized the specimens of mesoporous nanocrystalline $\mathrm{TiO}_{2}$ (the anatase phase with spherical crystallites less than $10 \mathrm{~nm}$ in size and various textural characteristics) and showed that their use as precursors allows the specimens of titanate nanotubes with various textures to be fabricated. The titanate nanotube specimens synthesized from the $\mathrm{TiO}_{2}$ ones (anatase with a crystallite dimension of $9.0 \mathrm{~nm}$, $S_{\mathrm{sp}}=86 \mathrm{~m}^{2} / \mathrm{g}$, a pore volume of $0.69 \mathrm{~cm}^{3} / \mathrm{g}$, and a pore diameter of $17.3 \mathrm{~nm}$ ) are composed of homogeneous smooth nanotubular particles about $8 \mathrm{~nm}$ in diameter, more than $1 \mu \mathrm{m}$ in length, and open at both ends, which are assembled into bundles about $64 \mathrm{~nm}$ in diameter, which form, in turn, the ensembles of particles ranging from 2.7 to $3.2 \mu \mathrm{m}$ in size. When the nanotubes are heated up to a temperature of $300{ }^{\circ} \mathrm{C}$, anatase in their walls crystallizes (the size of crystallites is $5.7 \mathrm{~nm}$ ), which results in a change of the specific surface in the nanotube material from 254 to $190 \mathrm{~m}^{2} / \mathrm{g}$. Such an approach will allow one to find, in the future, the factors that affect the texture and the morphology of titanate nanotubes and to optimize the choice of a $\mathrm{TiO}_{2}$ precursor for synthesizing the titanate nanotubes with required structure and morphology, which will expand the prospects of obtaining the biomaterials with unique properties.

1. C.A. Grimes and G.K. Mor, in $\mathrm{TiO}_{2}$ Nanotube Arrays: Synthesis, Properties, and Applications (Springer, New York, 2009), p. 358.

2. X. Chen and S.S. Mao, Chem. Rev. 107, 2891 (2007).

3. S.M. Gupta and M. Tripathi, Chin. Sci. Bull. 56, 1639 (2011).

4. D.V. Bavykin, J.M. Friedrich, and F.C. Walsh, Adv. Mater. 18, 2807 (2006).

5. Y. Cui, H. Du, and L. Wen, J. Mater. Sci. Technol. 24, 675 (2008).

6. H.-H. Ou and S.-L. Lo, Separat. Purif. Technol. 58, 179 (2007).

7. M. Uchida, H.M. Kim, T. Kokubo et al., J. Biomed. Mater. Res. A 64, 164 (2003).

8. X.X. Wang, S. Hayakawa, K. Tsuru et al., Biomaterials 23, 1353 (2002).

9. J.M. Wu, S. Hayakawa, K. Tsuru et al., Am. Ceram. Soc. 87, 1635 (2004).

10. F. Zhang, Z. Zheng, Y. Chen et al., J. Biomed. Mater. Res. 42, 128 (1998).

11. H.C. Cheng, S.Y. Lee, C.C. Chen et al., Appl. Phys. Lett. 89, 173902 (2006).

12. X. Liu, P.K. Chu, and C. Ding, Mater. Sci. Eng. 47, 49 (2004).

13. M. Long and H.J. Rack, Biomaterials 19, 1621 (1998).

14. A. Cambell, D. Hamai, and S.C. Bondy, Neurotoxicology 22, 63 (2001).

15. T. Kokubo, T. Matsushita, and H. Takadama, J. Eur. Ceram. Soc. 27, 1553 (2007).

16. T. Kokubo, H.M. Kim, and M. Kawashita, Biomaterials 24, 2955 (2003).

17. K.C. Popat, M. Elgroth, T. La Tempa et al., Biomaterials 28, 4880 (2007).

18. M. Paulose, K. Shankar, O.K. Varghese et al., Nanotechnology 17, 1446 (2006).

19. N.I. Ermokhina, V.I. Litvin, V.G. Ilyin, and P.A. Manorik, Ukr. Khim. Zh. 73, 21 (2007).

20. A.V. Korzhak, N.I. Ermokhina, A.L. Stroyuk, V.K. Bukhtiyarov, A.E. Raevskaya, V.I. Litvin, S.Ya. Kuchmiy, V.G. Ilyin, and P.A. Manorik, J. Photochem. Photobiol. A 198, 126 (2008).

21. T. Kasuga, M. Hiramatsu, A. Hoson et al., Adv. Mater. 11, 1307 (1999). 
22. T. Kasuga, M. Hiramatsu, A. Hoson et al., Langmuir 14, 3160 (1998).

23. M. Qamar, C.R. Yoon et al., J. Korean Phys. Soc. 49, 1493 (2006).

24. M. Qamar, C.R. Yoon et al., Catalysis Today 131, 3 (2008).

25. Q. Chen, W. Zhou et al., Adv. Mater. 14, 1208 (2002).

26. D. Wang, B. Yu, F. Zhou et al., Mat. Chem. Phys. 113, $602(2009)$.

27. G.H. Du, Q. Chen et al., Appl. Phys. Lett. 79, 3702 (2001).

28. Y. Yuan, W. Zhou, and B.-L. Su, Chem. Commun. XX, $1202(2002)$.

29. Q. Chen, G.H. Du, S. Zhang et al., Acta Crystallogr. B58, 587 (2002).

30. J. Yu, H. Yu, B. Cheng et al., J. Mol. Catal. A 249, 135 (2006).

31. M.A. Khan, H.-T. Jung, and O.-B. Yang, J. Phys. Chem. B 110, 6626 (2006).

32. L. Zhang, H. Lin, N. Wang et al., J. Alloys Compounds 431, 230 (2007).

33. L.Q. Weng, S.H. Song et al., J. Eur. Ceram. Soc. 26, 1405 (2006).

34. E. Morgado, jr., M.A.S. de Abreu et al., Solid State Sci. 8, 888 (2006).
35. M. Kruk and M. Jaroniec, Chem Mater. 13, 3169 (2001).

Received 04.11.11.

Translated from Russian by O.I. Voitenko

СИНТЕЗ НАНОТРУБОК З МЕЗОПОРИСТОГО

НАНОКРИСТАЛІЧНОГО ДИОКСИДУ ТИТАНУ

Н.I. Ермохіна, В.А. Невинсъкий, П.А. Манорик, В.Г. Ілъӥн, М.М. Циба, А.М. Пузій, М.М. Щербатюк, Д.А. Климчук

$\mathrm{P}$ е $з$ ю м е

Золь-гель синтезом 3 подальшою гідротермальною обробкою було отримано зразки мезопористого нанорозмірного $\mathrm{TiO}_{2}$ (анатаз з розміром сферичних кристалітів менше 10 нм і діаметром пор понад 17 нм), з яких гідротермальним процесом у концентрованому розчині лугу при $130{ }^{\circ} \mathrm{C}$ синтезовано титанатні нанотрубки. Текстура і морфологія нових матеріалів була досліджена за допомогою методів SEM, TEM, XRD і ізотерм адсорбції-десорбції $\mathrm{N}_{2}$. Однорідні нанотубулярні частинки, відкриті з обох боків, діаметром $\sim 8$ нм і довжиною більше 1 мкм зібрані в пучки товщиною $\sim 64$ нм, які, в свою чергу, утворюють агломерати. Кальцинування на повітрі при $300{ }^{\circ} \mathrm{C}$ титанатних нанотрубок приводить до кристалізації в їх стінках анатазу (розмір кристалітів становить 5,7 нм), що супроводжується зменшенням питомої поверхні зразка від $255 \mathrm{~m}^{2} /$ г до $190 \mathrm{~m}^{2} / \mathrm{M}$. 